\title{
MENJADIKAN DEWAN RISET DAERAH DKI JAKARTA \\ SEBAGAI LEMBAGA INTERMEDIASI DAN ALIH TEKNOLOGI
}

\section{OPTIMIZATION THE DKI JAKARTA REGIONAL RESEARCH COUNCIL INTERMEDIATION AND TECHNOLOGY TRANSFER INSTITUTION}

\author{
Rais Rozali
}

Pusat Riset Kelautan, Badan Riset dan Sumber Daya Manusia

Komplek Bina Samudera Jl. Pasir Putih II Lantai 4-5, Ancol Timur, Jakarta Utara 14430

e-mail : gerbang13@yahoo.com

Diterima tanggal: 12 Desember 2021 ; diterima setelah perbaikan: 20 Desember 2021 ; Disetujui tanggal: 24 Desember 2021

\begin{abstract}
ABSTRAK
Dewan Riset Daerah DKI Jakarta (DRD) dibentuk untuk memberdayakan lembaga penelitian dan pengembangan serta IPTEK pengembangan kegiatan penelitian dan pengembangan. Pelaksanaan tugas dan fungsi DRD tidak disertai peran intermediasi maupun alih teknologi, yang relatif vital, dimana didalamnya ada fungsi audit dan kliring kelayakan teknologi yang dihasilkan atau akan diadopsi melalui kegiatan penilaian tingkat kesiapterapan teknologi. Patut dipertimbangkan untuk mengubah struktur maupun kelembagaan, sehingga pemanfaatan teknologi untuk meningkatkan pelayanan maupun kesejahteraan masyarakat Provinsi DKI Jakarta dapat berjalan dengan baik.
\end{abstract}

Kata Kunci: Dewan Riset Daerah DKI Jakarta, Lembaga, Intermediasi, Alih Teknologi.

\section{ABSTRACT}

The DKI Jakarta Research Council (DRD) was formed to empower research and development institutions as well as science and technology for the development of research and development activities. The implementation of DRD duties and functions is not accompanied by the role of intermediation or technology transfer, which is relatively vital, in which there is an audit function and clearing of the feasibility of the technology produced or to be adopted through technology readiness level assessment activities. It is worth considering changing the structure and institutions, so that the use of technology to improve services and the welfare of the people of DKI Jakarta Province can run well.

Keywords: DKI Jakarta Research Council, Institution, Intermediation, Technology Transfer. 


\section{PENDAHULUAN}

Abad 21 merupakan abad pengetahuan yang ditandai dengan intrusi pengetahuan ke dalam setiap aspek kehidupan masyarakat. Pengetahuan telah menjadi bagian yang tidak dapat dipisahkan dari kehidupan masyarakat dimana tuntutan akan peningkatan kesejahteraan semakin tinggi. Dalam berbagai entitas terutama dalam bidang bisnis, pengetahuan telah diakui menjadi aset tak berwujud yang keberadaannya seringkali jauh lebih bernilai daripada kegiatan produksi barang dan jasa itu sendiri. Karenanya pengelolaan pengetahuan menjadi agenda penting dalam peningkatan produktivitas suatu usaha. Dalam perspektif pemerintahan, pengelolaan pengetahuan (knowledge management) merupakan sumber informasi manajemen dalam mengambil setiap keputusan strategis terutama yang menyangkut upayaupaya penyejahteraan masyarakat melalui-programprogram pembangunan. Dewasa ini telah semakin banyak entitas yang menjadikan pengetahuan sebagai suatu aset untuk menentukan langkah-langkah strategis dalam mendorong pencapaian tujuan korporatnya.

Dalam penyelenggaraan pemerintahan, salah satu upaya pengelolaan pengetahuan dapat dimulai dengan mengidentifikasi potensi yang dihasilkan oleh sumbersumber pengetahuan, seperti unit-unit penelitian dan pengembangan (riset). Hasil riset yang dilakukan oleh unit-unit kerja yang menghasilkan riset yang ada di unit-unit kerja Pemerintahan DKI Jakarta maupun dari unit kerja nonDKI Jakarta sedapat mungkin harus diintermediasi dan dikelola sebagai aset dan informasi manajemen yang strategis, terutama dalam rangka peningkatan kesejahteraan mapun pelayanan kepada masyarakat DKI Jakarta.

Provinsi DKI Jakarta tidak ada lembaga riset daerah yang secara khusus melakukan intermediasi hasil-riset yang dapat menjembatani alih teknologi antara unit, antar daerah, antar lembaga, dan dari luar ke dalam Pemerintahan DKI Jakarta atau sebaliknya. Di DKI Jakarta yang terkait riset secara khusus hanya ada dewan yang sifatnya indepeneden dan tidak memiliki fungsi teknis untuk melakukan intermediasi alih teknologi dan kekayaan intelektual, yaitu dewan Riset Daerah, berdasarkan Peraturan Gubernur Nomor 131 Tahun 2014 sebagai pengganti Peraturan Gubernur Nomor 101 tahun 2005 tentang pembentukan Dewan Riset Daerah.

Berdasarkan uraian sebelumnya dapat ditarik pokok permasalahan, bagaimana Dewan Riset Daerah DKI
Jakarta dapat lebih berperan dalam melakukan intermediasi dan alih teknologi? Diharapkan dapat menjelaskan peranan Dewan Riset Daerah DKI Jakarta untuk menjadi lembaga intermediasi dan alih teknologi.

\section{BAHAN DAN METODE}

Bentuk penelitian yang digunakan adalah penelitian yuridis-normatif, yaitu dengan menelaah dasar-dasar hukum intermediasi alih teknologi dan perlindungan serta pemanfaatan kekayaan intelektual (Yaqin, 2007; Marzuki, 2005). Tipe penelitian yang digunakan adalah penelitian deskriptif-eksploratif, dimana penelitian yang dilakukan guna memperoleh keterangan, penjelasan, dan data mengenai hal-hal yang dibahas dalam penelitian (Yaqin, 2007). Penelitian ini dilakukan melalui studi dokumen (Yaqin, 2007). Masalah hukum akan diletakan dengan cara melakukan identifikasi dan analisis terhadap berbagai peraturan perundang-undangan maupun data sekunder yang intermediasi alih teknologi dan perlindungan serta pemanfaatan kekayaan intelektual di Daerah DKI Jakarta. Data terkumpul kemudian diolah sedemikian rupa untuk kemudian didiskriptifkan untuk menjawab pokok permasalahan.

\section{HASIL DAN PEMBAHASAN}

\section{DRD DKI Jakarta}

Data yang kami peroleh dari website https://drdjakarta. id, Dewan Riset Daerah Provinsi Daerah Khusus Ibukota Jakarta (DRD) merupakan lembaga independen non struktural yang dibentuk berdasarkan Peraturan Gubernur Provinsi DKI Jakarta Nomor 131 Tahun 2014 sebagai pengganti Peraturan Gubernur Nomor 101 tahun 2005 tentang pembentukan Dewan Riset Daerah yang merupakan pelaksanaan undang-undang Nomor 18 Tahun 2002 tentang sistem nasional penelitian dan penerapan ilmu pengetahuan dan teknologi.

DRD terdiridari: parapakar,mantan Birokrat,Akademisi, Tenaga Ahli, Praktisi, Tokoh Masyarakat dan Unsur Organisasi Kemasyarakatan (LSM) yang berdedikasi dan berpartisipasi dalam pengentasan permasalahan di DKI Jakarta yang ditetapkan Berdasarkan Keputusan Gubernur Provinsi DKI Jakarta. DRD berkedudukan di bawah dan bertanggung jawab langsung kepada Gubernur dan secara operasional dikoordinasikan oleh Kepala Badan Perencanaan Pembangunan Daerah (Bappeda). Dan masa tugas anggota DPRD adalah 5 tahun hingga tahun 2022 dan dapat diangkat kembali sesuai kebutuhan dan kinerjanya. 
DRD Provinsi DKI Jakarta dibentuk untuk memberdayakan lembaga penelitian dan pengembangan serta IPTEK pengembangan kegiatan penelitian dan pengembangan yang ada di daerah serta untuk memperkuat penguasaan IPTEK serta merumuskan masukan bagi penyusunan kebijakan dan Prioritas pembangunan daerah sebagai instrumen untuk meningkatkan daya saing (Per. Gub. Prov. DKI Jakarta 131 /2014).

Pembentukan DRD Provinsi DKI Jakarta bertujuan untuk menstimulir, memfasilitasi serta mensinergikan unsur kelembagaan dan kegiatan sumber daya dan jaringan IPTEK di daerah dalam rangka merumuskan masukan bagi penyusutan penyusunan kebijakan dan Prioritas pembangunan daerah serta implementasi penelitian yang berbasis Iptek dan inovasi (Per. Gub. Prov. DKI Jakarta 131 /2014).

DRD merupakan Lembaga independen yang bertugas membantu pemerintah DKI Jakarta dalam pengembangan riset di semua Lini dan memberikan masukan atas isu-isu strategis yang berdampak penting kepada Gubernur secara langsung yang berkoordinasi dengan Bappeda dan SKPD/UKPD lainnya (Per. Gub. Prov. DKI Jakarta 131 /2014).

Berdasarkan informasi tersebut yang ada di website https://drdjakarta.id, maupun Peraturan Gubernur Provinsi DKI Jakarta Nomor 131 Tahun 2014 sebagai pengganti Peraturan Gubernur Nomor 101 tahun 2005 tentang pembentukan Dewan Riset Daerah, DRD tidak memiliki peran intermediasi maupun alih teknologi, fungsinya hanya melakukan pemetaan maupun perumusan kebijakan pembangunan ilmu pengetahuan dan teknologi. Padahal dalam pemanfaatan riset, yang vital adalah fungsi intermediasi dan alih teknologi. Dimana didalamnya ada fungsi audit dan kliring kelayakan teknologi yang dihasilkan atau akan di adopsi melalui kegiatan penilaian tingkat kesiapterapan teknologi (TKT), sebagaimana diatur dalam Peraturan Menteri Ristekdikti Nomor 42 Tahun 2016 tentang Pengukuran dan Penetapan Tingkat Kesiapterapan Teknologi.

Untuk menjadikan ilmu pengetahuan dan teknologi sebagai pendukung pokok upaya meningkatkan pelayanan maupun kesejahteran masyarakat perlu lembaga khusus yang didalamnya terdapat ahli-ahli dalam bidang intermediasi, alih teknologi, maupun penilaian kelayakan teknologi. Pemanfataan teknologi tidak bisa asal-asalan, karena akan berakibat pada kerugian masyarakat.
Menurut hemat kami ketiadaan lembaga riset milik DKI Jakarta dan Peran DRD yang tidak signifikan seharusnya disikapi dengan menaikan tugas dan fungsi DRD. Selain itu secara kelembagaan nantinya menjadi bagian dari struktur formal yang berada di bawah Gubernur DKI.

Sebagai gambaran, lebih lanjut akan dijelaskan bagaimana pengaturan terkait dengan intermediasi, alih teknologi maupun penilaian TKT. Gambaran ini diharapkan dapat membuka wacana baru perihal peran DRD.

\section{Intermediasi dan Alih Teknologi}

Menurut (Howells, 2006), intermediasi memfokuskan upaya untuk membangun jembatan dan menutup kesenjangan antara aktor kunci dari sistem inovasi yang mencakup perusahaan, universitas, dan organisasi penelitian publik. Hasil-hasil riset yang ada di DKI Jakarta seharusnya dapat dikelola dengan baik yang diarahkan untuk meningkatkan kesejahteraan masyarakat, juga untuk meningkatkan kualitas riset yang dilaksanakan. Dengan demikian, pengelolaan pengetahuan memiliki pola kerja yang menjembatani kepentingan sektor hulu (sumber pengetahuan) dan sektor hilir yaitu pemanfaatan hasil-hasil riset untuk pengambilan kebijakan strategis dan peningkatan layanan masyarakat. Dalam tataran operasional sistem inovasi bergerak secara interaktif dan saling sinergi antar para aktor, sehingga mampu menghasilkan produk-produk teknologi yang inovatif dan memiliki daya saing (kompetitif) (Freeman, 1987) dalam (Warseno, 2015).

Menurut (Lakitan, 2010), paling tidak ada tiga persoalan pokok terkait kinerja lembaga R\&D saat ini, yakni: kontribusi lembaga R\&D dalam pembangunan ilmu pengetahuan dan teknologi belum memenuhi harapan, terutama terindikasi dari sedikitnya publikasi ilmiah dan paten yang dihasilkan; kontribusi lembaga R\&D terhadap pembangunan perekonomian masih belum kentara, terutama terindikasi dari masih sangat terbatasnya teknologi domestik yang diadopsi dalam proses produksibarang ataujasa; dan kontribusi lembaga R\&D juga masih sangat terbatas dalam menyediakan solusi bagi persoalan yang dihadapi bangsa dan negara, secara praktis terlihat dari ketergantungan pada teknologi impor dalam menghadapi persoalan kebencanaan.

Perubahan ekonomi berbasis ilmu pengetahuan, yang disertai dengan langkah penerapan manajemen pengetahuan (knowledge management), bergantung pada penciptaan transformasi dan kapitalisasi dari 
pengetahuan (Sawarjuwono dan Kadir, 2003). Agar pengetahuan dapat memberikan nilai tambah serta memberikan umpan balik bagi kegiatan secara kelembagaan maka pengetahuan harus dikapitalisasikan dalam bentuk portofolio-portofolio perlindungan seperti hak kekayaan intelektual yang meliputi: hak cipta, paten, merek, desain industri, desain tata letak sirkuit terpadu, perlindungan varietas tanaman, dan perlindungan desain dan tata letak sirkuit terpadu.

Untuk mendukung pengelolaan pengetahuan tersebut maka peran lembaga intermediasi menjadi sangat signifikan. Lembaga intermediasi dapat diarahkan sebagai simpul pengetahuan (knowledge hub) yang mengintermediasi sumber pengetahuan dengan pihak yang memanfaatkannya. Dengan demikian, semakin tinggi pemanfaatan suatu hasil riset mengindikasikan bahwa pengetahuan yang dihasilkan oleh institusi tersebut memiliki kualitas yang memadai dan keselarasan dengan kebutuhan masyarakat. Era reformasi birokrasi menghendaki bahwa setiap program-program kegiatan Pemerintah harus dapat memberikan dampak langsung bagi masyarakat dan peran lembaga intermediasi menjamin terjadinya akselarsi program kelembagaan yang dibutuhkan oleh masyarakat (Nawawi, 2012).

Sesuai dengan ketentuan yang tercantum dalam Undang Undang Nomor 11 Tahun 2019 Tentang Sistem Nasional Ilmu Pengetahuan dan Teknologi, penerapan ilmu pengetahuan dan taknologi salasatunya dilakukan melalui kegiatan intermediasi dan alih teknologi hasil Penelitian, Pengembangan, dan/atau Pengkajian, yang dilaksanakan untuk mendorong Inovasi sebagai upaya peningkatan produktivitas pembangrlnan, kemandirian, dan daya saing bangsa.

Intermediator diperlukan untuk mengembangkan dan mendorong pertumbuhan ekonomi secara berkelanjutan dan meningkatkan pioduktivitas serta daya saing. Intermediasi Teknologi merupakan upaya untuk menjembatani proses terjadinya Invensi dan Inovasi antara penghasil dan calon pengguna Teknologi. Intermediasi Teknologi dapat dilakukan dengan: a. mendorong implementasi hasil Invensi dari lernbaga penghasil Teknologi kepada calon pengguna; dan b. mengidentifikasi kebutuhan calon pengguna terhadap Teknologi yang dibutuhkan. Intermediasi Teknologi dapat berupa: a. inkubasi Teknologi; b. temu bisnis Teknologi; c. kemitraan; dan/atau d promosi hasil Invensi (UU 11/2019).

Alih teknologi kekayaan intelektual dan hasil kegiatan penelitian dan pengembangan merupakan suatu kegiatan yang bertujuan mentransfer kemampuan untuk memanfaatkan dan menguasai ilmu pengetahuan dan teknologi dari satu pihak (pemberi) ke pihak lain (penerima) yang dapat berupa kekayaan intelektual dan hasil kegiatan penelitian dan pengembangan yang bersifat codified/explicit knowledge atau tacit (Dalkir, 2011; Tacit dan Explicit, https://sis.binus. ac.id/2018/05/04/15041/ Knowledge, diakses tanggal 13 Desember 2021; Pengelolaan Intelectual Property Pemerintah https://zalirais.wordpress.com/2013/09/27/ pengelolaan-intelectual-property-pemerintah, diakses tanggal 13 Desember 2021). Alih teknologi kekayaan intelektual dan hasil kegiatan penelitian dan pengembangan bersifat codified/explicit knowledge apabila tertuang dalam bentuk informasi yang tertata dengan baik sehingga dapat diakses, dipelajari, dan dipahami oleh pihak lain ((Dalkir, 2011). Sedangkan, alih teknologi kekayaan intelekual dan hasil kegiatan penelitian dan pengembangan dikatakan bersifat tacit apabila tidak tertuang dalam bentuk informasi yang tertata dengan baik, masih dalam bentuk pengetahuan dan pengalaman dari pelaku iptek atau dalam bentuk informasi yang hanya difahami oleh pelaku yang terlibat (Dalkir, 2011).

Alih teknologi yang relevan atas kekayaan intelektual dan hasil kegiatan penelitian dan pengembangan yang dihasilkan oleh lembaga penelitian dan pengembangan diharapkan dapat mendorong inovasi-inovasi yang bermutu dan pemberian penghargaan bagi pelaku penelitian dan pengembangan. Oleh karena itu, alih teknologi yang dilakukan juga harus dapat memacu hasrat pelaku riset untuk mengembangkan teknologi lebih lanjut baik yang ada atau pun belum ada. Untuk melaksanakan kegiatan alih teknologi ini diperlukan Mekanisme atau cara dan perencanaan matang untuk alih teknologi kekayaan intelektual dan hasil kegiatan riset baik yang bersifat codified knowledge maupun tacit knowledge transfer.

Alih teknologi kekayaan intelektual dan hasil kegiatan riset tidak dapat berjalan dengan baik dan sesuai tujuan apabila badan usaha atau penerima tidak siap dan tidak mampu untuk memenuhi persyaratan mutu, kinerja dan sumber daya lainnya (Tampubolon, 2013). Oleh karena itu, lembaga intermediasi sangat dominan dalam melakukan kerjasama atau kemitraan dengan badan usaha.

Alih Teknologi adalah pengalihan kemampuan memanfaatkan dan menguasai Ilmu Pengetahuan dan Teknologi antarlembaga, badan, atau orang, baik yang 
berada dalam lingkungan dalam negeri maupun yang berasal dari luar negeri ke dalam negeri atau sebaliknya. Alih Teknologi dilaksanakan melalui: a. lisensi; $b$. kerja sama; c. pelayanan jasa Ilmu Pengetahuan dan Teknologi; dan/atau d. pelaksanaan Alih Teknologi yang dilakukan dengan tidak bertentangan dengan ketertiban umum dan ketentuan peraturan perundangundangan (UU 11/2019 dan PP 20/2005).

Sebagaimana telah dijelaskan sebelumnya, bahwa fungsi intermediasi dan alih teknologi hanya akan berjalan dengan baik apabila didukung dengan kliring dan audit teknologi yang baik melalui TKT. TKT merupakan tingkat kondisi kematangan atau kesiapterapan suatu hasil Penelitian (research) dan pengembangan teknologi tertentu yang diukur secara sistematis dengan tujuan untuk dapat diadopsi oleh pengguna, baik oleh pemerintah, industri maupun masyarakat.

TKT diterapkan oleh National Aeronautics and Space Administration (NASA) sebagai alat untuk mengukur kesiapan teknologi yang dikembangkan oleh Stan Sadin pada tahun 1974 dan pertama kali digunakan oleh Ray Chase untuk melakukan assessment terhadap Jupiter Orbiter Spacecraft Design. TKT tersebut dikembangkan oleh NASA pada tahun 1980 yang konsep semula hanya terdiri atas 7 tingkat (level), kemudian dikembangkan menjadi 9 tingkat.

Pada tahun 2003, pengukuran TKT pertama kali dilakukan oleh NASA, digunakan sebagai alat untuk menyeleksi vendor teknologi yang sesuai dengankebutuhannya, dalam rangka mengurangi risiko kegagalan. Selanjutnya Kementerian Pertahanan Amerika Serikat juga mengadopsi metoda pengukuran ini untuk mengevaluasi tingkat kesiapterapan teknologi baru dan panduan pengembangannya di masa datang sampai siap secara operasional.

Masalah utama dalam adopsi teknologi adalah tingkat kesiapannya untuk digunakan dan dikembangkan menjadi inovasi, dan salah satu karakteristik inovasi adalah tingkat kesiapterapannya untuk digunakan. Namun, untuk bisa menentukan apakah sebuah teknologi dapat dikatakan siap untuk diadopsi oleh pengguna, dikomersialisasikan atau dijual, diperlukan suatu indikator dalam mengukur teknologi. Untuk mendapatkan gambaran kesiapterapan teknologi hasil penelitian serta membantu menentukan strategi pengembangan dan pemanfaatannya diperlukan pengukuran TKT.

Pengukuran TKT merupakan pendekatan sistematis yang digunakan untuk menilai kematangan atau kesiapterapan dari suatu teknologi tertentu dan perbandingan kematangan atau kesiapterapan antara jenis teknologi yang berbeda. Salah satu keuntungan melakukan penilaian kesiapterapan teknologi adalah dapat mengestimasi risiko dan biaya untuk pengembangan produk selanjutnya serta memutuskan kapan teknologi tersebut siap untuk dialihteknologikan ke industri. TKT dinilai dari sembilan tingkat yang terbagi lagi menjadi tiga kategori atau bagian tahapan penelitian yaitu: Penelitian Dasar (tingkat 1-3), Penelitian Terapan (tingkat 4-6) dan Penelitian Pengembangan (tingkat 7-9) (Gambar 1).

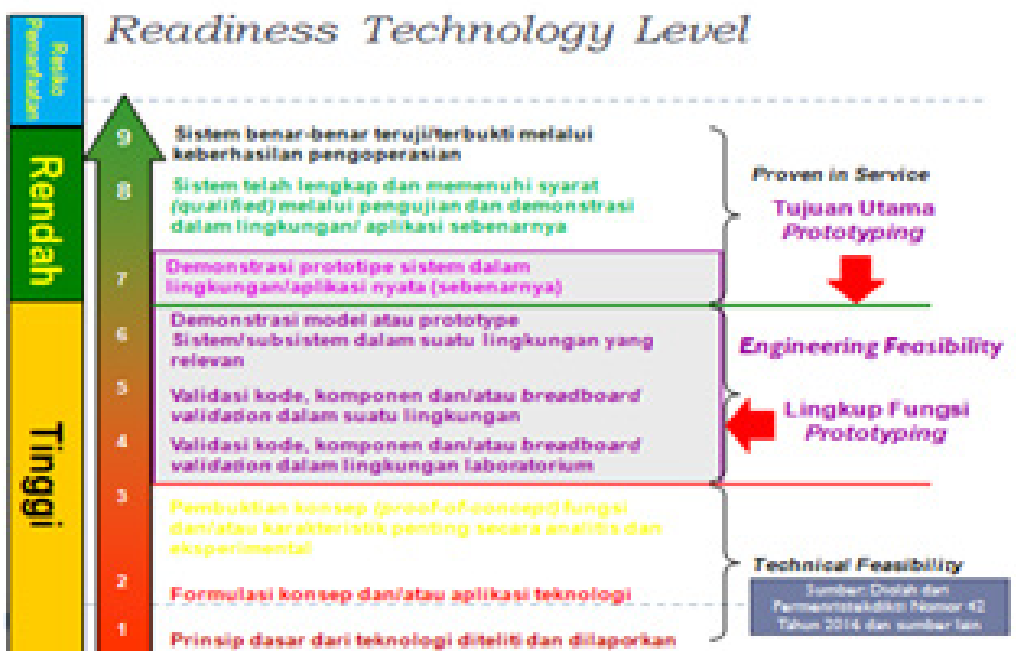

Gambar 1. Tingkat Kesiapanterapan Teknologi. (Sumber : Sumber: diolah dari Permenristekdikti Nomor 42 Tahun 2016 dan sumber lain (Arwanto, Prayitno, dan Suhendri, 2011; Héder, 2017, article 3, Technology Readiness Level, www.nasa.

gov/directorates/heo/scan/engineering/technology/technology readiness level, diakses tanggal 13 Desember 2021;

Technology readiness levels (TRL), Horizon 2020 - Work Programme 2014-2015, diakses tanggal 13 Desember 2021).

Menjadikan Dewan Riset Daerah DKI Jakarta Sebagai Lembaga Intermediasi dan Alih Teknologi - Rais Rozali 


\section{DRD "Wajah Baru"}

Belum terlaksananya tugas dan fungsi intermediasi dan alih teknologi yang didukung dengan TKT diharapkan dapat diatasi dengan strategi penyelenggaraan yang difokuskan pada empat area yang dibidangi DRD "Wajah Baru" yaitu:

Penguatan Kelembagaan DRD, merupakan upaya untuk memperlengkapi lembaga dengan instrumen kelembagaan yang memadai sehingga memiliki tugas dan fungsi satuan kerja organik di bawah Gubernur. Status kelembagaan diperlukan sebagai komitmen untuk mendorong intermediasi dan alih teknologi sebagai bagian dari kinerja lembaga.

Penguatan SDM, ditujukan untuk mendidik para pengelola yang profesional dalam melaksanakan tugas dan fungsi intermediasi dan alih teknologi. Pengetahuan para pengelolan merupakan modal dasar untuk mengembangkan dan mengarahkan lembaga menjadi unit kerja yang bekerja secara multidisiplin dan terintegrasi. Pengembangan SDM dapat dilakukan melalui jalur formal (S1, S2, dan S3) serta jalur informal lainnya seperti kursus-kursus yang diselenggarakan di dalam maupun di luar negeri (Yusdinal, 2008).

Training, merupakan kegiatan peningkatan kemampuan dan kesadaran pengelola yang ditujukan untuk menjaring hasil-hasil kegiatan litbang yang dilakukan oleh para peneliti sehingga dapat dikapitalisasikan (Yusdinal, 2008). Kapasitas absorptif dapat dihasilkan dengan berbagai cara. Tiga cara utama bagi organisasi untuk melakukannya, adalah: berinvestasi dalam R\&D in-house, produk sampingan dari operasi manufaktur, mengirim personil ke pelatihan teknis lanjutan, faktor kritis, oleh karena itu, adalah komunikasi di tingkat antar-organisasi (Spithoven et al., 2011).

Kegiatan Intermediasi dan Alih Teknologi, kegiatan membangun jejaring dengan industri maupun pengguna dalam rangka pemanfaatan teknologi. kerjasama dapat dilakukan dengan dua strategi yaitu kerjasama dalam perencanaan riset serta kerjasama dalam memanfaatkan hasil riset. Tujuan dari kerjasama adalah link and match sehingga sejak awal penelitian peneliti telah memposisikan pemanfaatan hasil penelitian tersebut. Memahami bahwa kapasitas absorptif tidak harus hanya terjadi hanya dalam tingkat kelembagaan yang besar, tetapi dapat terjadi pada tingkat antar-organisasi, menimbulkan pertanyaan tentang jenis peran yang mungkin dimainkan perantara teknologi. Berikut tiga kegiatan utama intermediasi yang saling terkait meningkatkan kapasitas inovasi:
- Intermediasi teknologi bertindak sebagai knowledge intelligence units. Bertugas untuk memantau perkembangan teknologi eksternal melalui, misalnya, kegiatan menonton teknologi dan pemetaan jalan teknologi adalah salah satu tugas utama mereka.

- Bertindak sebagai knowledge agencies. Bertugas untuk memberi saran secara proaktif proyek penelitian ke pusat-pusat riset. Bersadarkan saran tersebut, intermediator mengatasi masalah yang dihadapi dan, lebih jauh lagi, menerapkan teknologi.

- Bertindak sebagai repository of knowledge. Kegiatan ini diarahkan pada penyebaran informasi di antara jaringan. Dengan menyebarkan alat, pustaka, dan membuatnya tersedia untuk jaringan, sehingga mampu meningkatkan kemampuan asimilasi antar jaringan (Spithoven et al., 2011).

\section{KESIMPULAN DAN SARAN}

Berdasarkan uraian sebelumnya dapat diambil kesimpulan dan saran sebagai berikut:

- Kegiatan dan hasil riset yang bermanfaat bagi DKI Jakarta sedapat mungkin harus diintermediasi dan dilakuan proses alih teknologi dalam rangka peningkatan kesejahteraan mapun pelayanan kepada masyarakat DKI Jakarta.

- DRD tidak memiliki peran intermediasi maupun alih teknologi, dimana didalamnya ada fungsi audit dan kliring kelayakan teknologi yang dihasilkan atau akan diadopsi melalui kegiatan penilaian TKT, sehingga teknologi yang diadopsi benar-benar telah siap dan berfungsi dengan baik.

- Diperlukan penguatan Kelembagaan DRD 'Wajah Baru' yang merupakan satuan kerja organik di bawah Gubernur, yang diisi oleh SDM yang kompeten dalam bidang intermediasi dan alih teknologi serta penilaian TKT.

\section{UCAPAN TERIMA KASIH}

Terima kasih kepada Tim Editorial Jurnal Riset Jakrta, khususnya kepada Dr. -Ing. Widodo Setiyo Pranowo dan Sekretariat Redaksi Jurnal Riset Jakarta.

\section{DAFTAR PUSTAKA}

Yaqin, A. (2007). Legal Research and Writing. Selangor: Lexisnexis.

Dalkir, K. (2011). Knowledge Management in Theory and Practice. 2nd Edition, Cambridge: TMP, 2011, dalam Tacit dan Explicit, https://sis.binus. 
ac.id/2018/05/04/15041/ Knowledge.

Marzuki, P.H. (2005). Penelitian Hukum, Jakarta: Kencana Prenada Media Group.

Tampubolon, S. (2013). Politik Hukum Iptek di Indonesia, Yogyakarta: Kepel Press.

Yusdinal, (2008). Perlindungan Hukum Terhadap Lisensi Paten. Semarang: Tesis Universitas Dipenogoro.

Spithoven, A., Clarysse, B., \& Knockaert, M. (2011). Building absorptive capacity to organise inbound open innovation in traditional industries. Technovation, 31(1), 10-21.

Arwanto., Prayitno, K.B., Suhendri, D. (2011). TeknoMeter: Panduan Pengukuran Tingkat Kesiapan Teknologi. BPPT, Pusat Pengkajian Kebijakan Difusi Teknologi.

Lakitan, B. (2010). Revitalisasi Kelembagaan Riset dan Pengembangan untuk Mendukung Sistem Inovasi Nasional. seminar Revitalisasi Kelembagaan Litbang yang diselenggarakan di Pascasarjana Universitas Sahid, Jakarta.

Howells, J. (2006). Intermediation and the role of intermediaries in innovation. Research Policy. 35(5), 715-728.

Héder, M. (2017). From NASA to EU: the evolution of the TRL scale in Public Sector Innovation, The Innovation Journal: The Public Sector Innovation Journal, 22(2).

Sawarjuwono, T., \& Kadir, A.P. (2003). Intellectual capital: perlakuan, pengukuran, dan pelaporan (sebuah library research). Jurnal akuntansi dan keuangan, 5(1), 35-57.

Warseno. (2015). Hubungan Jaringan Lembaga Penyedia dengan Lembaga Regulasi terhadap Implementasi PP 20 Tahun 2005. Journal of Industrial Engineering \& Management Systems, $8(2)$.

Nawawi, I. (2012). Manajemen Pengetahuan (Knowledge Management), Bogor: Ghalia Indonesia.

Technology Readiness Level (2021). https:www. nasa.gov/directorates/heo/scan/engineering/ technology/technology_readiness_level, diakses tanggal 13 Desember 2021.

Technology readiness levels (TRL). (2020). Horizon 2020 - Work Programme 2014-2015 https:// ec.europa.eu/research/participants/data/ref/ h2020/wp/2014_2015/annexes/h2020-wp1415annex-g-trl_en.pdf, diakses tanggal 13 Desember 2021.

Pengelolaan Intelectual Property Pemerintah. (2013). https://zalirais.wordpress.com/2013/09/27/ pengelolaan-intelectual-property-pemerintah/, diakses tanggal 13 Desember 2021.

DRD Jakarta. (2019). https://drdjakarta.id/index.php/ tentang-drd/sejarah.

Undang-Undang Nomor 11 Tahun 2019. (2019) tentang Sistem Nasional Ilmu Pengetahuan dan Teknologi (Lembaran Negara Republik Indonesia Tahun 2019 Nomor 148, Tambahan Lembaran Negara Republik Indonesia Nomor 6374).

Peraturan Pemerintah Nomor 20 Tahun 2005 tentang Alih teknologi kekayaan intelektual serta hasil kegiatan penelitian dan pengembangan oleh perguruan tinggi dan lembaga penelitian dan pengembangan.

Peraturan Menteri Ristekdikti Nomor 42 Tahun 2016 tentang Pengukuran dan Penetapan Tingkat Kesiapterapan Teknologi (Berita Negara Republik Indonesia Tahun 2016 Nomor 1010).

Peraturan Gubernur Provinsi DKI Jakarta Nomor 18 Tahun 2002 tentang pembentukan Dewan Riset Daerah sebagaimana telah diubah dengan Paraturan Gubernur Provinsi DKI Jakarta Nomor 101 tahun 2005.

Peraturan Gubernur Provinsi DKI Jakarta Nomor 131 Tahun 2014 tentang pembentukan Dewan Riset Daerah.

Peraturan Direktur Jenderal Pengutan Riset dan Pengebangan Kementerian Riset dan Teknologi dan Pendidikan Tinggi Nomor. 603/E1.2/2016 tentang Indikator Pengukuran Tingkat Kesiapterapan Teknologi. 
